\title{
Influence of the environmental characteristics of mangrove forests on recent benthic foraminifera in the Gulf of Urabá, Colombian Caribbean
}

\section{Influencia de las características ambientales de los manglares sobre foraminíferos bénticos recientes en el golfo de Urabá, Caribe colombiano}

\author{
Eliana Gómez*, Gladys Bernal \\ Grupo de investigación OCEANICOS (Oceanografía e ingeniería costera), Escuela de Geociencias y Medio \\ Ambiente, Facultad de Minas, Universidad Nacional de Colombia-Sede Medellín, Carrera 80 No 65-223. \\ * Corresponding author. E-mail: egomezoc@unal.edu.co
}

\begin{abstract}
Mangrove forests with different characteristics have developed in the Gulf of Urabá (Colombia). Eighty-two sediment samples were studied for species of foraminifera and their environmental dependence. Ten agglutinated species and one calcareous species dominated in these mangroves. Foraminifera were absent in mangrove areas exposed to high hydraulic energy (waves) or high human affectation. Two characteristic assemblages were found. The first one, represented by Milliammina fusca, the most dominant species, was related to finer substrates and lower salinities. The second one, represented by Ammonia beccarii, the most common calcareous species, was found in polluted low-oxygen environments. Haplophragmoides canariensis and Trochammina squamata, small species, showed a preference for places with abundant organic matter. A conceptual model is proposed that relates the benthic foraminifera to the hydrodynamics, grain size, organic matter content, and pollution.
\end{abstract}

Key words: ecology, benthic foraminifera, estuary, mangrove forests.

RESUMEN. En el golfo de Urabá (Colombia) ocurren varios bosques de manglar con diferentes características. En 82 muestras de sedimentos se estudiaron las especies de foraminíferos y su dependencia ambiental. Diez especies de concha algutinada y una de concha calcárea dominaron en estos manglares. No se observaron foraminíferos en zonas sometidas a alta energía hidráulica (oleaje) o alta intervención antropogénica. Se encontraron dos asociaciones características. La primera, representada por Milliammina fusca, la especie más dominante, se asoció con sustratos más finos y menores salinidades. La segunda, representada por Amonia beccarii, la especie calcárea más abundante, se asoció con ambientes contaminados y de bajo oxígeno. Haplophragmoides canariensis y Trochammina squamata, especies pequeñas, tuvieron preferencia por lugares con abundante materia orgánica. Los resultados permitieron plantear un modelo conceptual que relaciona los foraminíferos bénticos de los manglares con la hidrodinámica, el tamaño de grano, el contenido de materia orgánica y la contaminación.

Palabras clave: ecología, foraminíferos bénticos, estuario, manglares.

\section{INTRODUCTION}

Benthic foraminifera (BF) in mangrove environments are characterized by agglutinated tests (Murray 2006) and are smaller than in other environments, even less than $63 \mu \mathrm{m}$. Assemblages may vary from the mangrove to offshore in the percentage of agglutinated foraminifera, abundance, and diversity (Culver 1990).

Apparently, specific environmental factors acting on BF in mangrove ecosystems are diverse and may have complex relationships. Studies have shown that oxygen availability (Vanicek et al. 2000, Diz and Francés 2008), grain size (Debenay et al. 2002, Diz and Francés 2008, Chatelet et al. 2009, Mojtahid et al. 2009), amount and quality of organic matter (Wolfgang 1996, Nooijer et al. 2008, Chatelet et al. 2009), aerial exposure and vertical elevation (Debenay et al. 2002), marine and fresh water influence (Debenay and ThiLuan 2006, Mojtahid et al. 2009), geomorphology (Alongi and Robertson 1992), vegetal composition (Morrisey et al. 2003), and waves and currents (Culver 1990) are some of the

\section{INTRODUCCIÓN}

Los foraminíferos bénticos (FB) en ambientes de manglar se han caracterizado por presentar concha aglutinada (Murray 2006) y por ser de tamaños más pequeños que en otros ambientes, incluso menores que $63 \mu \mathrm{m}$. Las asociaciones pueden variar en el porcentaje de foraminíferos aglutinados, abundancias y diversidad, desde el manglar hacia fuera de la costa (Culver 1990).

Al parecer los factores ambientales específicos que actúan sobre los FB en manglares son diversos y pueden tener relaciones complejas. Estudios han mostrado que la disponibilidad de oxígeno (Vanicek et al. 2000, Diz y Francés 2008), el tamaño de grano (Debenay et al. 2002, Diz y Francés 2008, Chatelet et al. 2009, Mojtahid et al. 2009), la cantidad y calidad de materia orgánica (Wolfgang 1996, Chatelet et al. 2009, Nooijer et al. 2008), la exposición aérea y elevación vertical (Debenay et al. 2002), la influencia de agua marina y dulce (Debenay y Thi-Luan 2006, Mojtahid et al. 2009), la geomorfología (Alongi y Robertson 1992), la 
elements that influence the distribution and abundance of BF in these ecosystems.

The Gulf of Urabá (GU) is located on the western edge of the Colombian Caribbean, close to Panama (fig. 1). It is a semi-enclosed water body of approximately $2000 \mathrm{~km}^{2}$ and has different types of mangrove forests along the coast, which occupy about $70 \mathrm{~km}^{2}$. This estuarine system receives several river inputs, especially from the Atrato River, responsible for the second largest river discharge to the Caribbean Sea $\left(2421 \mathrm{~m}^{3} \mathrm{~s}^{-1}\right)$. This river forms a delta splitting GU into two parts, the southern part known as Colombia Bay. The river greatly influences the sediment and pollutant distribution inside GU; general circulation of the river plume is through the eastern margin (Montoya 2010).

Different mangrove forests are located in GU (fig. 1). (1) Atrato River delta mangroves: 78.3\%, well-developed forests (Urrego et al. 2010) in distributary channels, deltaic bays, and swamps between bars; slight anthropogenic affectation, only a few villages of not more than 350 inhabitants in the area (Taborda-Marín et al. 2008), but high degree of plant infection (32.5\%, Urrego et al. 2010). (2) Rionegro Cove mangroves: $7.2 \%$, early successional forests around a coastal lagoon delimited by sand bars; they present high anthropogenic affectation, 70 ha were lost in 2004 due to several reasons (Corpourabá 2011). (3) Turbo Bay and El Uno Bay mangroves: $2.9 \%$, the bays are separated from the main gulf by large barriers deposited by the Turbo River, the second largest in GU; highly intervened forests near the urban area of the town of Turbo, the biggest in the vicinity (135,967 inhabitants, http://www.turbo-antioquia.gov.co). (4) Mangroves at small river mouths: $17 \%$, small forests at the mouths of small rivers, usually highly affected by logging.

The GU provides an opportunity to study the ecology of $\mathrm{BF}$ in mangroves because of its different environments, degree of development, and anthropogenic affectation. Vargas (2011) studied BF in GU and found that salinity is the main factor controlling their distribution in the large estuary, but BF fauna in the mangroves has not been studied before. The aim of this work was to determine the biodiversity and distribution of BF in the GU mangrove forests and their relationship with several ecological factors such as sediments, water properties, morphology, and anthropic impact.

\section{MATERIAL AND METHODS}

A total of 82 sediment samples taken from the GU mangrove forests in June and August 2009 (wet season) and February 2010 (dry season), at depths between $3 \mathrm{~cm}$ and $5 \mathrm{~m}$, were analyzed (fig. 1). The number of samples was proportional to the area of each mangrove forest and with an approximate separation between stations of $2 \mathrm{~km}$, distributed as follows: 53 samples from the Atrato River delta, 14 from Rionegro Cove, 6 from Turbo and El Uno bays, and 9 from river mouths along the GU margin. Most samples were taken next to the mangroves (42) and the rest in the lagoons or composición vegetal (Morrisey et al. 2003) y las olas y corrientes (Culver 1990) son algunos de los factores que tienen influencia en la distribución y abundancia de los FB en estos ecosistemas.

En el límite oeste del Caribe colombiano, cerca de Panamá, se localiza el golfo de Urabá (GU) (fig. 1). El GU es un cuerpo de agua semicerrado de aproximadamente $2000 \mathrm{~km}^{2}$ y presenta diferentes tipos de manglares a lo largo de la costa, que ocupan unos $70 \mathrm{~km}^{2}$. Este sistema estuarino recibe descargas de varios ríos, en especial del río Atrato, el segundo caudal más grande que desemboca en el mar Caribe $\left(2421 \mathrm{~m}^{3} \mathrm{~s}^{-1}\right)$. Este río forma un delta que separa el GU en dos partes, de las cuales la parte sureña es un cuerpo semicerrado denominado bahía Colombia. El río tiene una gran influencia en los patrones de distribución de sedimentos y contaminantes dentro del GU; la circulación general hace que las aguas dulces de la pluma turbia salgan recostadas por el margen oriental (Montoya 2010).

En el GU se encuentran diferentes bosques de manglar (fig. 1). (1) Manglares del delta del río Atrato: 78.3\%, bosques muy bien desarrollados (Urrego et al. 2010) en canales distributarios, bahías deltaicas y pantanos entre barras; poca afectación antropogénica, sólo hay pequeñas poblaciones de máximo 350 habitantes en el área (Taborda-Marín et al. 2008), pero alto grado de infección fitosanitaria (32.5\%, Urrego et al. 2010). (2) Manglares de la ensenada de Rionegro: $7.2 \%$, bosques en estado sucesional temprano alrededor de una laguna costera delimitada por barras arenosas; presentan elevada influencia antropogénica, 70 hectáreas perdidas en 2004 por diversas causas (Corpourabá 2011). (3) Manglares de las bahías de Turbo y El Uno: 2.9\%, las bahías están separadas del cuerpo principal del GU por grandes barreras depositadas por el río Turbo, el segundo en importancia en el GU; bosques altamente intervenidos cerca de la zona urbana del municipio de Turbo, el más grande en las riberas del golfo, (135,967 habitantes, http://www.turboantioquia.gov.co). (4) Manglares en las bocas de cauces: $17 \%$, pequeños bosques en las desembocaduras de ríos menores, a menudo muy afectados por la tala.

El GU ofrece una oportunidad para estudiar la ecología de los FB en manglares, por su variedad de entornos, desarrollo y afectación antropogénica. Los FB del GU han sido estudiados por Vargas (2011), quien encontró que la salinidad es el principal factor que controla la distribución de éstos en el gran estuario, pero la fauna de FB en los manglares no ha sido estudiada. El objetivo de este trabajo fue determinar la biodiversidad y distribución de FB en los bosques de manglares del GU y su relación con algunos factores ecológicos como sedimentos, propiedades del agua, morfología y grado de afectación antropogénica.

\section{Metodología}

Se analizaron un total de 82 muestras tomadas de los sedimentos asociados con los manglares del GU en junio y agosto 


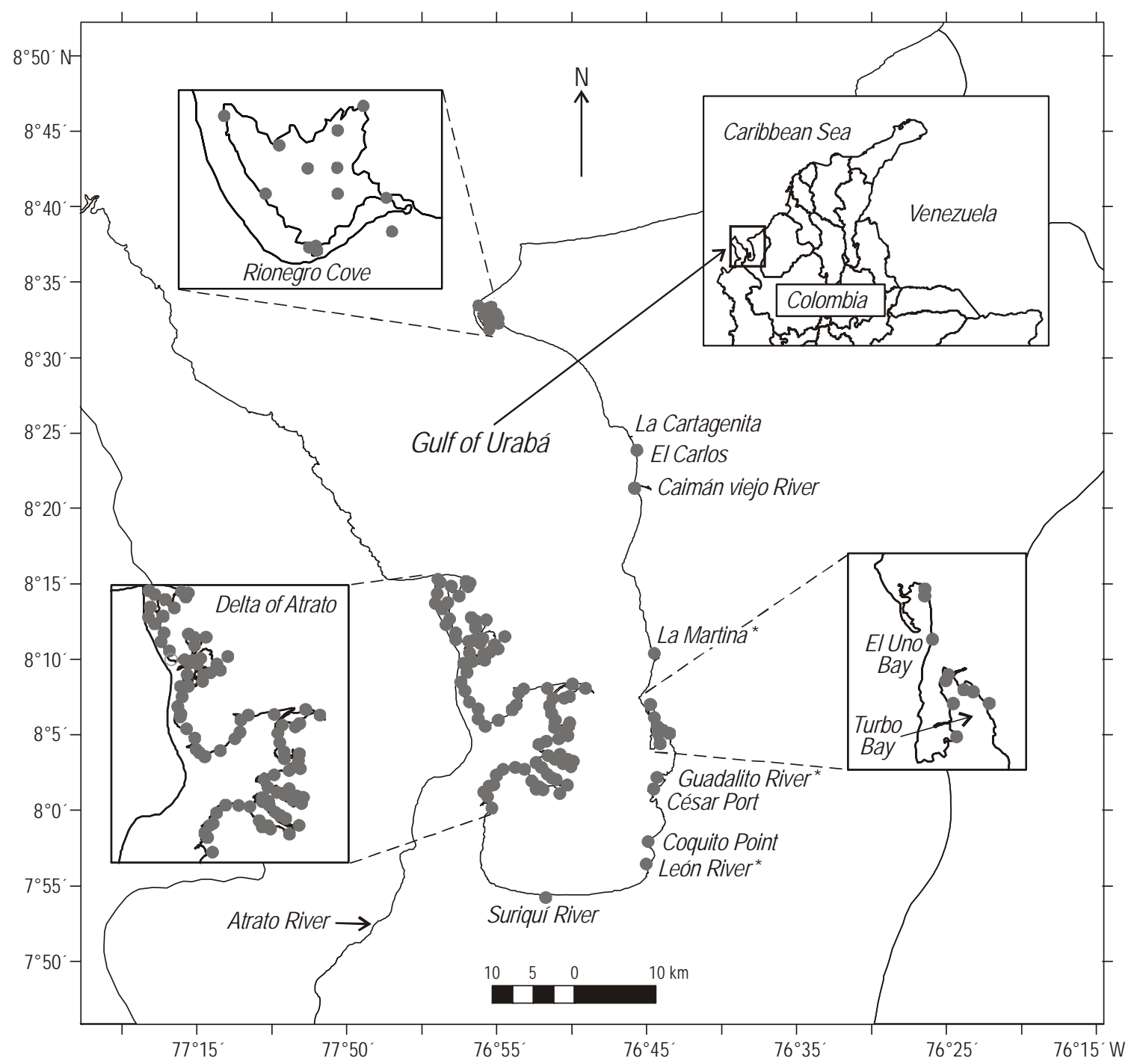

Figure 1. Location map of the study area showing the sampling sites (circles) in the mangrove forests of the Gulf of Urabá (Colombia). REDCAM stations indicated with asterisks.

Figura 1. Mapa del área de estudio donde se muestra la ubicación (círculos) de las muestras recolectadas en el golfo de Urabá (Colombia). Estaciones de REDCAM marcadas con asterisco.

associated channels. Surface sediments were collected with an Ekman dredge and samples of $100 \mathrm{~cm}^{3}$ of the first centimeter were taken. Twenty drops of $95 \%$ alcohol were added to the samples and, after 15 minutes, $70 \%$ alcohol was added and the samples were stored on ice (Murray 2006). Although BF can survive below several centimeters, only the first centimeter was collected in order to obtain recent shells. It has also been reported that the first surface centimeter is the most representative environmentally (Schonfeld et al. 2012), that assemblages of shallow environments show no significant changes with sediment depth (Sen Gupta 1999), and that the depth to which FB penetrate the sediment is largely controlled by the oxygen content (Gooday et al. 2000); hence, in mangrove environments, rich in organic matter, epibenthic habits are expected. Nonetheless, environmental de 2009 (época húmeda) y febrero de 2010 (época seca) a profundidades de entre $3 \mathrm{~cm}$ y $5 \mathrm{~m}$ (fig. 1). El número de muestras tomadas fue proporcional al área de cada bosque de manglar y con una separación aproximada de $2 \mathrm{~km}$ entre las estaciones, distribuidas de la siguiente manera: 53 muestras en los manglares del delta del Atrato, 14 en la ensenada de Rionegro, 6 en las bahías de Turbo y El Uno, y 9 en las bocas de cauces a lo largo del margen del golfo. La mayoría de las muestras fueron tomadas al lado de los mangles (42) y las demás, en las lagunas o canales asociados. Sedimentos superficiales fueron recolectados con una draga Ekman y se tomaron muestras de $100 \mathrm{~cm}^{3}$ del primer centímetro. A las muestras se les adicionaron 20 gotas de alcohol al 95\%, y 15 minutos después se les adicionó alcohol al 70\% y luego se conservaron en hielo (Murray 2006). Aunque los FB pueden 
interpretations from the superficial sediment may still underestimate infaunal species.

Salinity and temperature were measured with a YSI multiparameter probe. The oxygen sensor presented problems in the field and in situ oxygen data could not be obtained. Other water quality parameters were taken from the National Network for Marine Water Quality Monitoring reports (REDCAM 2010, http://www.invemar.org.co/psubcategorias.jsp?idsub=252\&idcat $=105$ ).

Sediments were washed through 355, 150, and $63 \mu \mathrm{m}$ meshes. To differentiate the live organisms during the collection, the three size fractions were stained with rose bengal as described in Murray (2006). Each dried fraction was divided depending on its size and counts were made in pre-weighed aliquots until at least 100 individuals were obtained, for a total of approximately 300 individuals per sample. In some samples it was not possible to complete the 300 individuals due to the scarcity of foraminifera. The number of individuals per sample was calculated taking into account the weights of aliquots and fractions.

Biocenosis was defined (rose bengal stained individuals) in order to differentiate the live and dead organisms at the moment of capture. Nonetheless, the total of individuals (live + dead) was used for the final analysis. The convenience of working with the total number of individuals is discussed by Debenay et al. (2002) and Chatelet et al. (2004), who show that it is a good indicator of environmental conditions.

Species were identified according to the classification of Loeblich and Tappan (Sen Gupta 1999) and the plates of Barker (1960), Buzas et al. (1977), McCulloch (1977), Buzas and Severin (1982), Boltovskoy and Hincapié de Martínez (1983), Parada and Pinto (1986), Parada (1991), Debenay et al. (2002), Debenay and Thi-Luan (2006), and Bernal et al. (2008).

Samples for sediment analysis were taken at the same time as sample collection for BF analysis. They were dried at $60^{\circ} \mathrm{C}$. Organic matter (OM) was measured by calcination and carbonates were measured using a Bernard calcimeter. Particle-size analysis of sand and mud was made separately by dry sieving and the pipette method. In small samples (with higher water contents relative to sediment) only percentages of mud $(\% \mathrm{M})$ and sand grain size were estimated. The grain size parameters of the mean, selection, and asymmetry were obtained by the method of moments (Tucker 1988).

Data analysis and statistical methods were used (correlation matrices and cluster analysis). The Shannon diversity index was calculated as described in Mojtahid et al. (2009). Finally, we performed a conceptual model of the main ecological factors affecting the distribution and abundance of benthic foraminifera in the GU mangrove forests.

\section{RESUlts}

Only at 35 locations were BF found (fig. 2), with maximum abundances of 66 ind $\mathrm{cm}^{-3}$. The highest abundances vivir enterrados varios centímetros, se muestreó el primer centímetro superficial buscando que las conchillas contenidas en el sedimento analizado fueran recientes. Además, se ha demostrado que el primer centímetro superficial es el más representativo ecológicamente (Schonfeld et al. 2012), que en ambientes someros no se han visto cambios significativos en las asociaciones con la profundidad (Sen Gupta 1999) y que la profundidad a la cual los FB penetran en los sedimentos es controlada en gran parte por el contenido de oxígeno (Gooday et al. 2000); por tanto, en ambientes de manglar, ricos en materia orgánica, se esperan hábitos preferencialmente epibénticos. Sin embargo, hay que tener en cuenta que las interpretaciones ambientales a partir de los sedimentos más superficiales pueden subestimar algunas especies infaunales.

La salinidad y temperatura fueron medidas con una sonda multiparamétrica YSI. La sonda para medir oxígeno presentó problemas en el campo y no se obtuvieron datos de oxígeno. Otros parámetros de calidad de agua fueron tomados de los informes del Monitoreo de Calidad del Agua del Invemar (REDCAM 2010, http://www.invemar.org.co/psubcategorias.jsp?idsub=252\&idcat $=105$ ).

Los sedimentos fueron lavados a través de tamices de 355, 150 y $63 \mu \mathrm{m}$. Con el fin de diferenciar los organismos vivos durante la colecta, las tres fracciones fueron teñidas con rosa de bengala como se describe en Murray (2006). Cada fracción seca fue dividida dependiendo de su tamaño y se hicieron conteos en alícuotas previamente pesadas hasta obtener al menos 100 individuos, para un total aproximado de 300 individuos por muestra. En algunas muestras no fue posible completar los 300 individuos debido a la escasez de foraminíferos. El número de individuos por muestra fue calculado tomando en cuenta los pesos de las alícuotas medidas y de las fracciones.

Se determinó la biocenosis (individuos teñidos con rosa de bengala), para diferenciar los organismos vivos de los muertos en el momento de la captura. Sin embargo, el total de individuos (vivos + muertos) fue utilizado en el análisis final. La conveniencia de trabajar con el total de individuos se discute en Debenay et al. (2002) y Chatelet et al. (2004), quienes muestran que el total de los individuos es un buen indicador de condiciones ambientales.

Para la identificación de las especies se usó la clasificación de Loeblich y Tappan (Sen Gupta 1999) y las planchas de Barker (1960), Buzas et al. (1977), McCulloch (1977), Buzas y Severin (1982), Boltovskoy e Hincapié de Martínez (1983), Parada y Pinto (1986), Parada (1991), Debenay et al. (2002), Debenay y Thi-Luan (2006) y Bernal et al. (2008).

Paralelo con la recolección de muestras para foraminíferos, se tomaron muestras para análisis sedimentológicos. Se secaron a $60^{\circ} \mathrm{C}$. Se midió la materia orgánica (MO) por calcinación y los carbonatos se midieron con un calcímetro de Bernard. La granulometría de arenas y lodos se hizo por separado, a través de tamizado en seco y el método de la pipeta. En muestras pequeñas (con alto contenido de agua 
occurred in the mangroves of the Atrato River delta and Turbo and El Uno bays (up to 66 and 26 ind $\mathrm{cm}^{-3}$, respectively); however, only two of six samples from this last locality contained foraminifera. In Rionegro Cove, BF were only found in two samples from the lagoon, with maximum values of 3 ind $\mathrm{cm}^{-3}$. In small forests along the GU shore, at the mouths of small rivers, we did not find BF.

A total of 18 genera and 26 species were identified (fig. 3); 12 species belong to the order Rotaliida (calcareous test) and 14 to the order Textulariida (agglutinated test). Agglutinated species abundances were higher, the most abundant being Milliammina fusca, while Ammonia beccarii was the most abundant calcareous species. The agglutinated $\mathrm{BF}$ were present in all samples containing foraminifera, with values between $55 \%$ and $100 \%$ (except Rionegro Cove, where the only species was the calcareous foraminifera $A$. beccari). the Shannon-Weaver index showed values between 0 and 0.66 .

Eleven species of BF, ten of them agglutinated, had the highest abundances (>5 ind $\mathrm{cm}^{-3}$ ): M. fusca (61\%), Haplophragmoides canariensis (7\%), Ammobaculites exiguus (7\%), Trochammina squammata (5\%), Ammobaculites exiliis (5\%), Ammotium salsum (3\%), Ammobaculites americanus (3\%), Arenoparrella mexicana (2\%), Ammonia beccarii (2\%), Trochammina inflata (1\%), and Haplophragmoides wilbertii (1\%). The species stained with rose bengal were M. fusca and A. exilis. Haplophragmoides canariensis and T. squammata preferred the smallest fraction $(63-150 \mu \mathrm{m})$; $87 \%$ of the former and $67 \%$ of the latter were smaller than $150 \mu \mathrm{m}$. In turn, A. exiguus, A. exilis, A. salsum, T. inflata, and $A$. mexicana preferred the $150-355 \mu \mathrm{m}$ fraction.

Cluster analysis with the abundances of the most common species at the 35 localities where BF were found (fig. 4) revealed two main groups (G1 and G2). The G1 locations had the highest abundances of A. salsum, A. mexicana, and A. beccari, while the G2 locations had the highest abundances of $M$. fusca, $H$. canariensis, A. exiguus, T. squammata, A. exilis, A. americanus, $T$. inflata, and $H$. wilbertii. The G1 abundances of $M$. fusca were less than 8 ind $\mathrm{cm}^{-3}$, while those of G2 were higher (between 8 and 42 ind $\mathrm{cm}^{-3}$ ). Salinity reached 20 at the G1 locations and 12 at the G2 locations. The G1 sediments had up to $41 \%$ of carbonates, while the G2 sediments only up to $6 \%$. G1 had the largest sediment sizes and lowest BF abundances. There was no difference in the percentage of agglutinated species between the two groups.

The two main groups are in turn divided into subgroups (g1 to g6, table 1). The two G1 subgroups differed in regard to OM content (higher in g2), carbonates (higher in g2), and \%M (higher in g1). The four G2 subgroups showed decreasing abundances and grain sizes.

Correlations between the variables characterizing the environment and foraminifera were low. Salinity, temperature, and depth did not have significant relationships with BF, because of their homogeneity among sampled sites. Significant correlations were observed for $H$. canariensis and respecto al sedimento) sólo se estimaron los porcentajes de lodos (\%L) y el tamaño de granos. Los parámetros granulométricos de la media, la asimetría y la selección fueron obtenidos por el método de los momentos (Tucker 1988).

Para analizar los datos se utilizaron métodos estadísticos como matrices de correlación y análisis de conglomerados. Se calculó el índice de diversidad de Shannon como se describe en Mojtahid et al. (2009). Finalmente, se realizó un modelo conceptual de los principales factores ecológicos que están afectando la distribución y abundancia de los foraminíferos bénticos en los manglares del GU.

\section{RESUltados}

Sólo en 35 localidades se encontraron FB (fig. 2), con abundancias máximas de 66 ind $\mathrm{cm}^{-3}$. Las mayores abundancias ocurrieron en los manglares del delta del río Atrato y de las bahías Turbo y El Uno (hasta 66 y 26 ind $\mathrm{cm}^{-3}$, respectivamente); sin embargo, sólo en dos muestras de 6 de esta última localidad hubo foraminíferos. En la ensenada de Rionegro sólo se encontraron FB en dos muestras, con valores máximos de 3 ind $\mathrm{cm}^{-3}$. En los pequeños bosques de la ribera del $\mathrm{GU}$, en las bocas de ríos menores, no se encontraron FB.

Un total de 18 géneros y 26 especies fueron identificados (fig. 3); 12 de las especies pertenecen al orden Rotaliida (concha calcárea) y 14 al orden Textulariida (concha aglutinada). Las especies aglutinadas presentaron las abundancias más altas, y Milliammina fusca fue la más abundante. Por su parte, Ammonia beccarii fue la especie calcárea con mayor ocurrencia. Los FB aglutinados estuvieron presentes en todas las muestras donde se presentaron foraminíferos, con valores entre 55\% y 100\% (a excepción de la ensenada de Rionegro, donde sólo se presentó la especie calcárea A.beccari). El índice de Shannon Weaver presentó valores entre 0 y 0.66.

Once especies de FB, diez de ellos aglutinados, tuvieron las mayores abundancias (> 5 ind $\mathrm{cm}^{-3}$ ): $M$. fusca (61\%), Haplophragmoides canariensis (7\%), Ammobaculites exiguus (7\%), Trochammina squammata (5\%), Ammobaculites exiliis (5\%), Ammotium salsum (3\%), Ammobaculites americanus (3\%), Arenoparrella mexicana (2\%), Ammonia beccarii (2\%), Trochammina inflata (1\%) y Haplophragmoides wilbertii (1\%). Las especies que se tiñeron con rosa de bengala fueron $M$. fusca y A. exilis. Haplophragmoides canariensis y $T$. squammata mostraron preferencia por la fracción más pequeña $(63-150 \mu \mathrm{m}) ; 87 \%$ de los individuos de $H$. canariensis y $67 \%$ de $T$. squamata midieron menos de $150 \mu \mathrm{m}$. Por su parte, A. exiguus, A. exilis, A. salsum, T. inflata y A. mexicana prefirieron la fracción de 150-355 $\mu \mathrm{m}$.

$\mathrm{El}$ análisis de conglomerados con las abundancias de las especies más comunes en las 35 localidades donde se presentaron FB (fig. 4) indicó dos grupos principales (G1 y G2). Las localidades del G1 tuvieron las abundancias más altas de A. salsum, A. mexicana y A. beccari, mientras que las localidades del G2 tuvieron las abundancias más altas de 

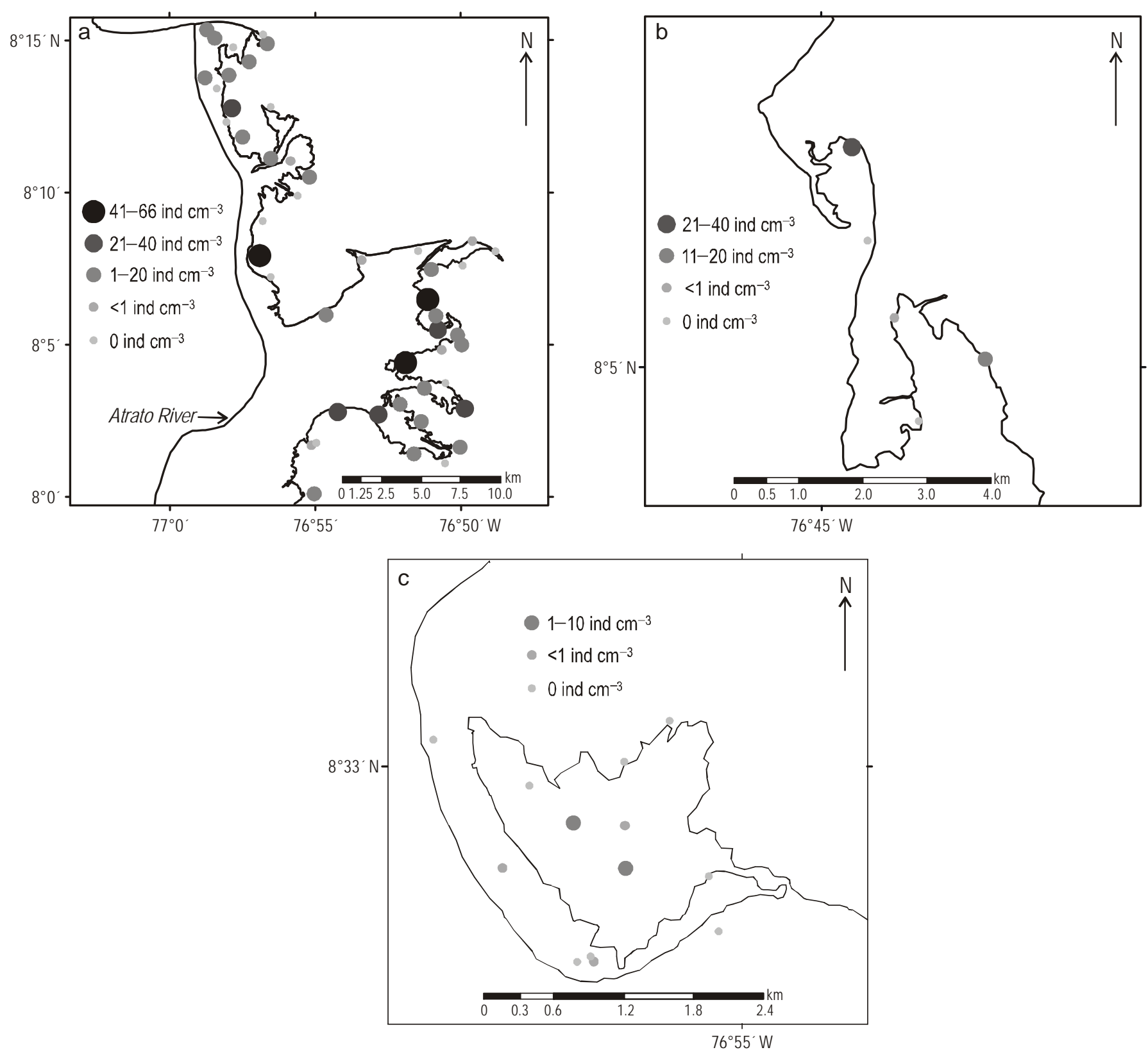

Figure 2. Distribution of benthic foraminiferal abundance: (a) Atrato River delta, (b) Turbo and El Uno bays, and (c) Rionegro Cove.

Figura 2. Distribución de las abundancias totales de foraminíferos bénticos: (a) delta del río Atrato, (b) bahías Turbo y El Uno, y (c) ensenada de Rionegro.

T. squamata with $\mathrm{OM}(0.26$ and 0.31$)$ and $T$. inflata with $\% \mathrm{M}(0.22)$.

According to REDCAM (fig. 5), dissolved oxygen levels were below $4 \mathrm{mg} \mathrm{L}^{-1}$ (minimum value of the Colombian norm) at the mouths of the rivers León, Guadualito, and Caimán Nuevo, locations where there were no BF, as well as at Rionegro Cove, where BF only occurred in 2 of 12 samples, from the middle part of the lagoon. Nutrient (phosphate, nitrate, and ammonium) values above the norm were found at Guadualito River mouth, La Martina Beach, and Rionegro Cove (without BF). Coliforms were measured only on
M. fusca, $H$. canariensis, A. exiguus, T. squammata, A. exilis, A. americanus, $T$. inflata y $H$. wilbertii. El G1 incluyó muestras con abundancias de $M$. fusca menores que 8 ind $\mathrm{cm}^{-3}$, mientras que el G2 incluyó muestras con mayores abundancias (entre 8 y 42 ind $\mathrm{cm}^{-1}$ ). La salinidad en las estaciones del G1 llegó hasta 20 y en las del G2, hasta 12; los sedimentos del G1 tuvieron hasta $41 \%$ de carbonatos, mientras que los del G2 sólo hasta $6 \%$. El G1 tuvo los tamaños más grandes de sedimento y las menores abundancias de FB. No hubo diferenciación del porcentaje de especies aglutinadas entre los dos grupos. 


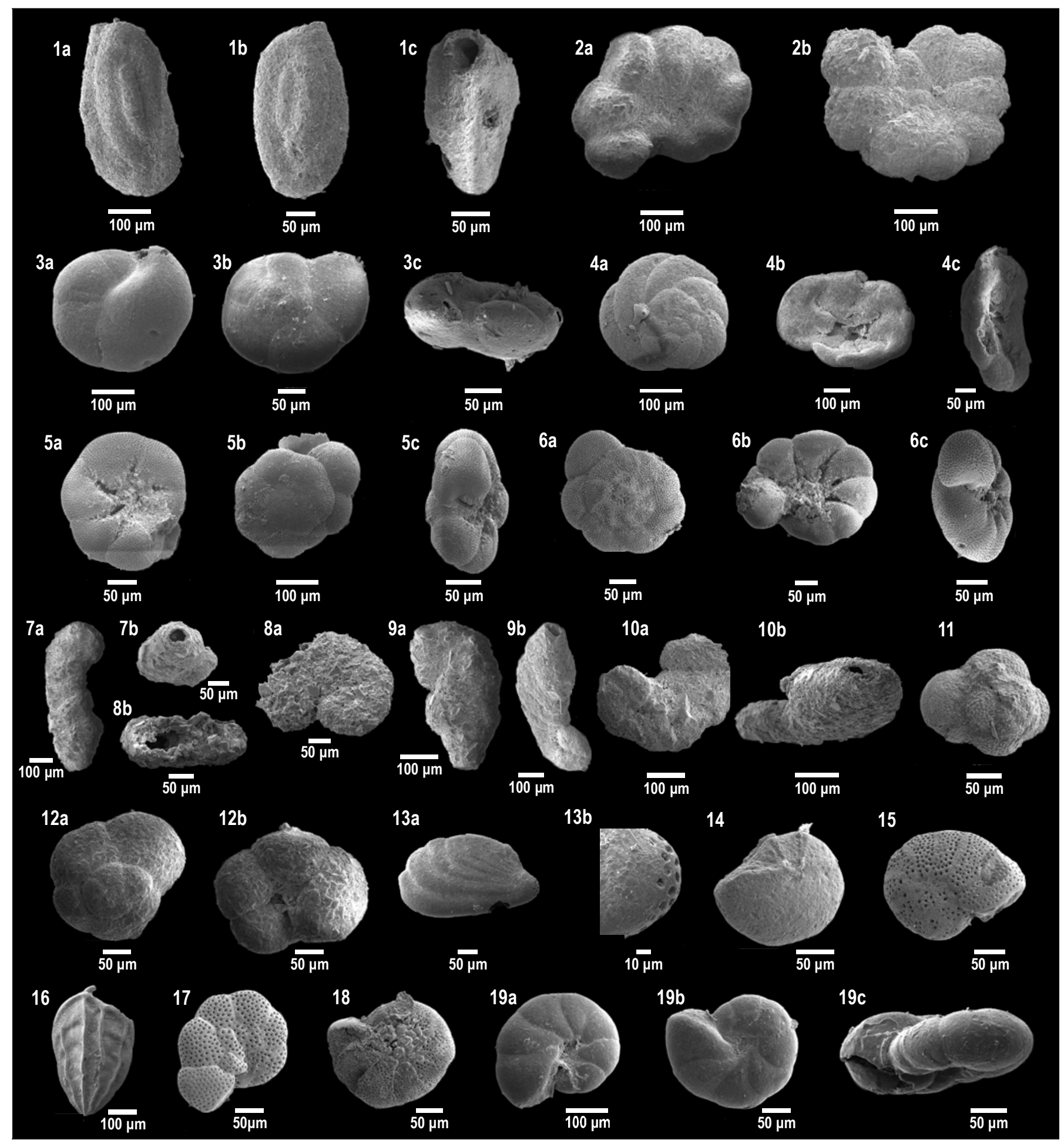

Figure 3. Electron microscope images of the species of foraminifera found.

Figura 3. Imágenes de microscopio electrónico de las especies de foraminíferos encontradas.

1: Milliammina fusca (Debenay \& Luan). 2: Haplophragmoides canariensis (Barker). 3: Arenoparrella mexicana (Kornfeld). 4: Trochammina squamata (Barker). 5: Ammonia beccarii (Linné). 6: Ammonia differens (McCulloch). 7: Ammobaculites exilis (Cushman \& Brönnimann). 8: Ammobaculites americanus (Cushman). 9: Ammotium salsum (Cushman \& Brönnimann). 10: Ammobaculites exiguus (Cushman \& Brönnimann). 11: Rosalina cf globulariformis (McCulloch). 12: Trochammina inflata (Montagu). 13: Amoastuta inepta (Cushman \& McCulloch). 14: Cellanthus gunteri (Cole). 15: Anomalinoides kurtzi (McCulloch). 16: Bolivina cf arenosa (Chapman). 17: Discorbis granulosa (Heron-Allen \& Earland). 18: Elphidium mexicanum (Kornfeld). 19: Haplophragmoides wilbertii (Andersen). 


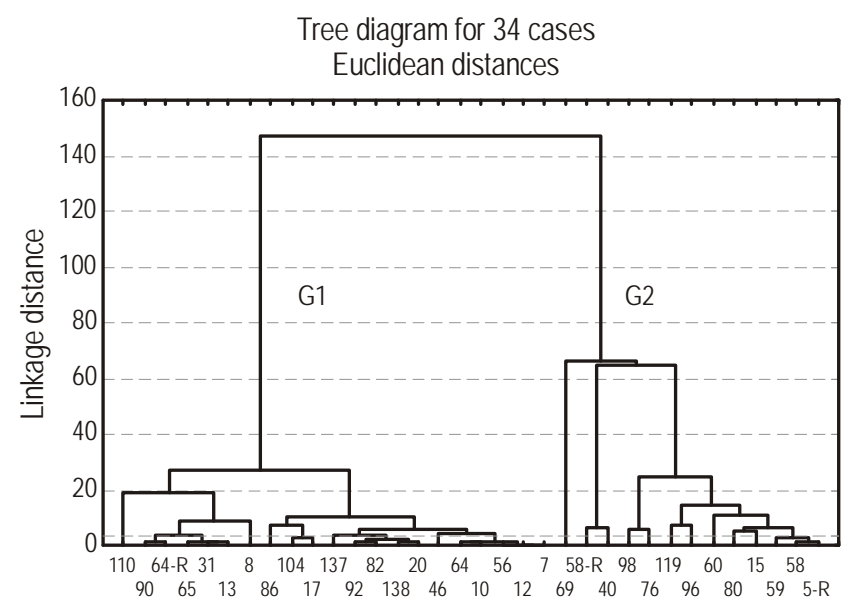

Figure 4. Dendrogram obtained by cluster analysis (Ward's method). Two groups (G1 and G2) are shown.

Figura 4. Dendrograma obtenido del análisis de conglomerados (método de Ward). Se indican dos grupos (G1 y G2).

beaches and were beyond the norm in La Martina and Turbo, where BF were also scarce.

The relationships found are summarized in the conceptual model presented in figure 6. Mangrove hydrodynamics and morphology influence the grain size; the localities exposed to waves have coarse sediments, lower \%OM, and no BF. Sheltered localities have muddy substrates and higher \%OM, favoring $M$. fusca. When OM values increase, carbonates decrease. Agglutinated foraminifera are favored by acid $\mathrm{pH}$. In anthropogenically affected mangroves, $\mathrm{BF}$ are absent or occur in low abundances, $A$. beccarii dominates, and low values of dissolved oxygen in water (anoxia) are common.

\section{DISCUSSION}

In comparison with other studies using similar methodologies in mangrove environments (considering the top $1 \mathrm{~cm}$ of sediment and all grain sizes), BF abundances in GU mangrove forests for grain sizes $>63 \mu \mathrm{m}\left(0-66\right.$ ind $\left.\mathrm{cm}^{-3}\right)$ have the same order of magnitude (e.g., French Guiana,
Los dos grupos se dividieron en subgrupos (g1 a g6, tabla 1). Los dos subgrupos del G1 se diferenciaron por sus contenidos de MO (mayor en g2), carbonatos (mayor en g2) y \%L (mayor en g1). Los cuatro subgrupos de G2 mostraron abundancias y tamaños de grano decrecientes.

Las correlaciones entre las variables que caracterizan los foraminíferos y las variables ambientales fueron bajas. La salinidad, temperatura y profundidad no tuvieron relaciones significativas con los FB, debido a su homogeneidad entre los sitios muestreados. Correlaciones significativas se presentaron entre $H$. canariensis y $T$. squamata con MO (0.26 y 0.31) y $T$. inflata con \% L (0.22).

De acuerdo con REDCAM (fig. 5), se registraron niveles de oxígeno disuelto menores que $4 \mathrm{mg} \mathrm{L}^{-1}$ (valor mínimo según la norma colombiana) en las bocas de los ríos León, Guadualito y Caimán Nuevo, localidades donde no se encontraron FB, así como en la ensenada de Rionegro, donde sólo hubo FB en dos de 12 muestras, al centro de la laguna. Valores de nutrientes (fosfatos, nitratos y amonio) por encima de la norma se encontraron en la boca del río Guadualito, la playa La Martina y la ensenada de Rionegro (sin presencia de FB). Los coliformes sólo se midieron en playas y sobrepasaron la norma en La Martina y Turbo, donde igualmente hubo déficit de FB.

Las relaciones encontradas se sintetizan en el modelo conceptual que se presenta en la figura 6. La hidrodinámica del manglar y su morfología influyen sobre el tamaño de grano; las localidades expuestas al oleaje presentan tamaños gruesos, menor \%MO y ausencia de FB. Las localidades resguardadas presentan sustratos lodosos y mayor \%MO, que favorecen a $M$. fusca. Cuando los valores de MO aumentan, disminuyen los porcentajes de carbonato. El desarrollo de foraminíferos aglutinados se ve favorecido con el $\mathrm{pH}$ ácido. En manglares con influencia antropogénica hay ausencia o bajas abundancias de FB, dominancia de $A$. beccarii y bajos valores de oxígeno disuelto en el agua (anoxia).

\section{DISCUSIÓN}

En comparación con estudios que consideran hasta $1 \mathrm{~cm}$ superficial y todos los tamaños de grano, las abundancias de

Table 1. Comparison of variables among the groups obtained by cluster analysis.

Tabla 1. Paralelo entre las variables de los grupos resultantes en el análisis de conglomerados.

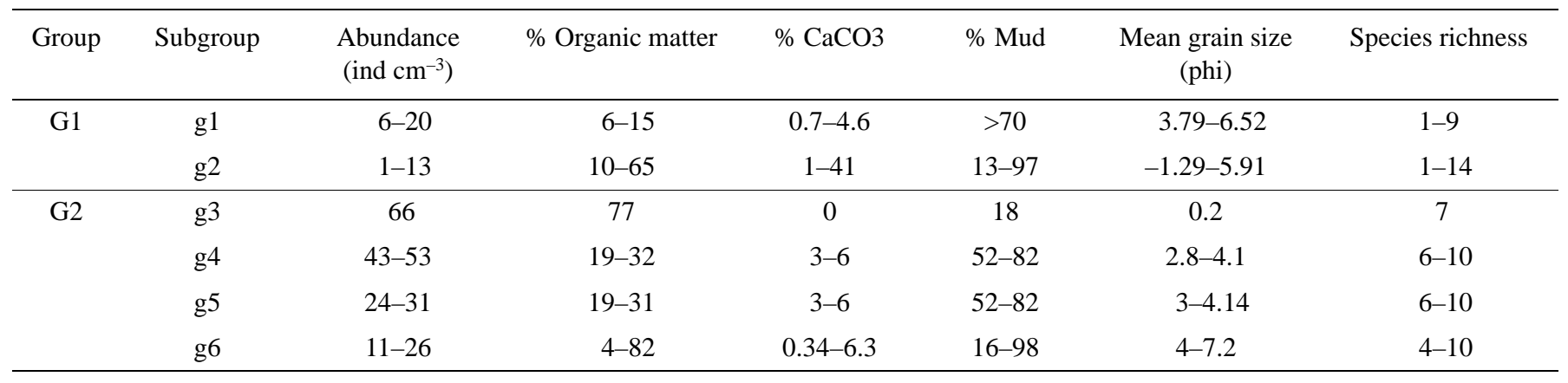



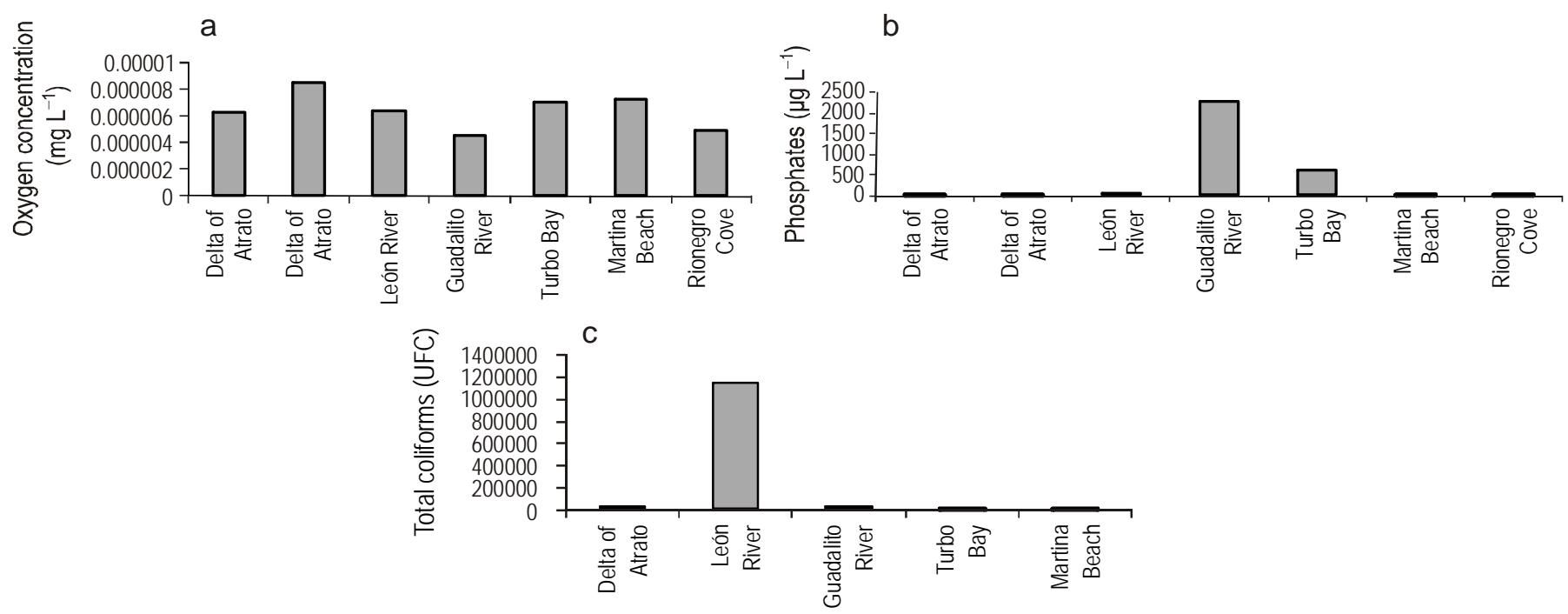

Figure 5. Bar graph showing the concentration of (a) dissolved oxygen, (b) phosphates, and (c) total coliforms. Data obtained from REDCAM (Invemar).

Figura 5. Gráfica que muestra la concentración de (a) oxígeno disuelto, (b) fosfatos y (c) coliformes totales. Datos obtenidos de REDCAM (Invemar).

4 Increase

$\downarrow$ Decrease

$\mathrm{CaCO}_{3}$ : calcium carbonate

H. Energy: Hidraulic energy
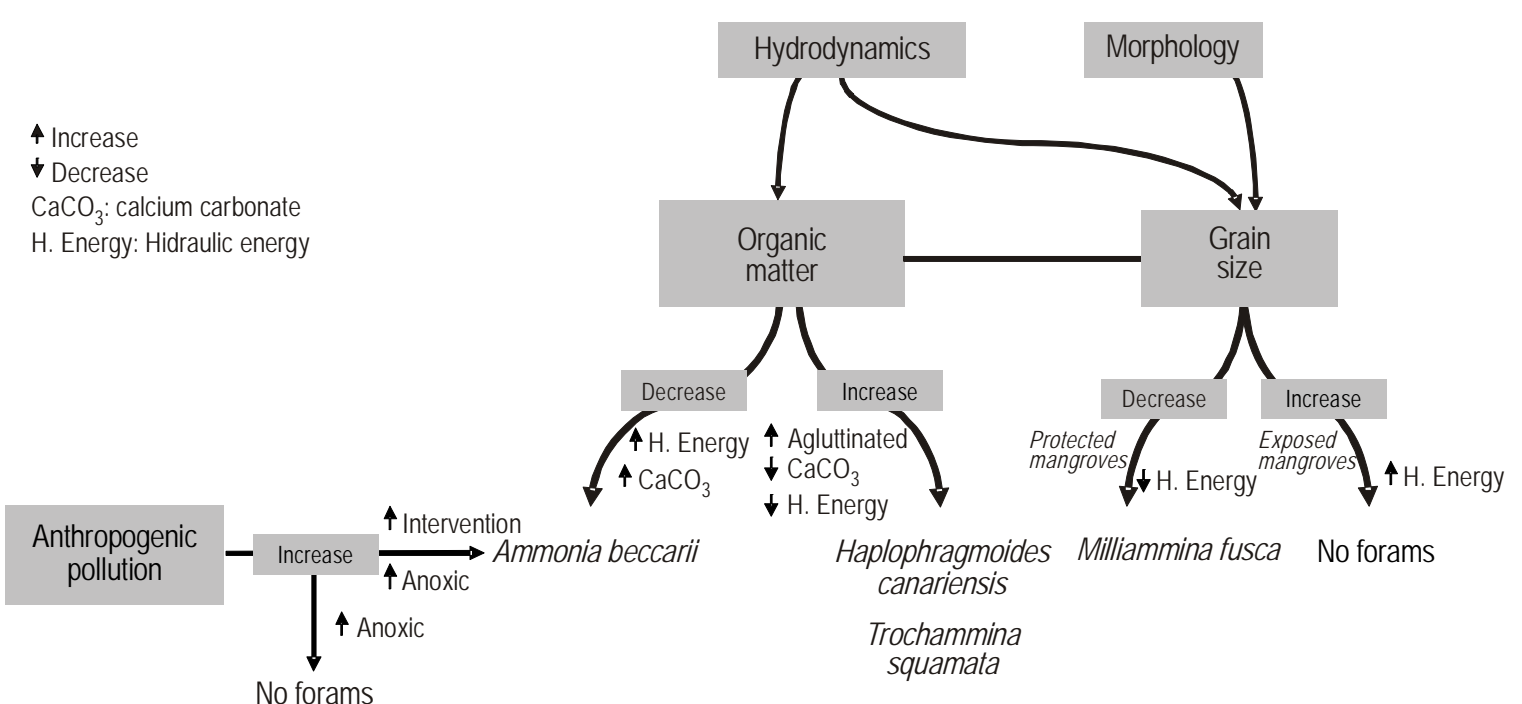

Haplophragmoides Milliammina fusca No forams canariensis

Trochammina squamata

Figure 6. Scheme showing the influence of ecological factors on benthic foraminifera from the Gulf of Urabá mangrove forests according to the results obtained in this study.

Figura 6. Esquema tentativo donde se resume la influencia de factores ecológicos sobre foraminíferos bénticos en los manglares del golfo de Urabá según los resultados obtenidos en este estudio.

0-40 ind $\mathrm{cm}^{-3}$, Debenay et al. 2002; Mekong Delta, Vietnam, 0.2-300 ind $\mathrm{cm}^{-3}$, Debenay and Thi-Luan 2006; Ría de Vigo, Spain, 20-80 ind $\mathrm{cm}^{-3}$, Diz and Francés 2008). The abundances in the mangrove forests are lower than in the main water body of GU (up to 92 ind $\mathrm{cm}^{-3}$, Vargas 2011). Species richness (26 species) is consistent with results obtained by other authors in estuarine environments (Debenay et al. 2002, Debenay and Thi-Luan 2006, Bernal et al. 2008, Mojtahid et al. 2009, Semensatto et al. 2009), but below those reported for the open GU (60 species, Vargas 2011). Likewise,
FB en GU para las fracciones $>63 \mu \mathrm{m}\left(0-66\right.$ ind $\left.\mathrm{cm}^{-3}\right)$ tienen los mismos órdenes de magnitud que en otros ambientes de manglar (e.g., Guyana Francesa, $0-40$ ind $\mathrm{cm}^{-3}$, Debenay et al. 2002; delta del Mekong, Vietnam, 0.2-300 ind $\mathrm{cm}^{-3}$, Debenay y Thi-Luan 2006; Ría de Vigo, España, 20-80 ind $\mathrm{cm}^{-3}$, Diz y Francés 2008). Las abundancias en los manglares son más bajas que en el cuerpo de agua principal del GU (hasta 92 ind $\mathrm{cm}^{-3}$, Vargas 2011). La riqueza de esepcies (26 especies) es congruente con resultados obtenidos por otros autores en ambientes estuarinos (Debenay et al. 2002, 
biodiversity was low (Shannon-Weaver index from 0 to 0.66). Low abundance and diversity in estuaries and mangroves can be attributed to non-optimal salinity and $\mathrm{pH}$ conditions for BF (Mojtahid et al. 2009).

Foraminifinal faunal composition was dominated by a single species, $M$. fusca, with $61 \%$ of the total. This species was also dominant in the Tina Minor estuary, Cantabria (Pascual et al. 2009). In GU, M. fusca was found mainly in the Atrato mangroves where silty substrates with high \%M (up to 90\%) dominated. This species has occurred in environments with very low salinity (Debenay et al. 2002, Murray 2006), with \%M lower than 66\% (Murray 2006), in clay-rich sediments (Chatelet et al. 2009), and stressed environments (Semensatto et al. 2009); it is not favored by plant debris deposits on sediments (Chatelet et al. 2009).

The species assemblage found is characteristic of these environments. Horton et al. (2003) observed the predominance of $M$. fusca, A. mexicana, and $H$. canariensis in an Australian mangrove ecosystem. Ammobaculites exiguus has been reported in shallow estuarine environments where salinity does not exceed 20 (Scott 2007), associated with muddy sediments and tolerant to air exposure (Semensatto et al. 2009). In GU mangrove forests, A. exiguus showed a preference for sandy muds in some Atrato localities. In turn, $T$. squamata has been characterized as preferring fine substrates (Murray 2006), rich in OM (Chatelet et al. 2009). In the GU mangroves it was also associated with \%M and, together with H. canariensis, with OM.

The most important calcareous species was A. Beccari. In a sample from Rionegro Cove it represented $100 \%$ relative to other species. It is a common species but has the ability to colonize mangrove and estuarine environments (Debenay et al. 2002, Diz and Francés 2008, Mojtahid et al. 2009). It is associated with high levels of OM and low oxygen concentrations in the sediments (Scott 2007, Diz and Francés 2008). Its dominance in Rionegro Cove could be due to the low oxygen levels recorded by REDCAM.

To analyze the relationships between BF and the environmental conditions, total abundances in samples and environmental parameters at the time of collection were taken into account. A weakness of the analysis is that the samples were collected during three months, in two different seasons. An analysis of seasonal variability was not performed, which would certainly be valuable but requires a specific sampling design. The use of total BF (live + dead) in the first centimeter implies a long-term rather than seasonal relationship with the environment.

Previous research has shown that small fractions (63-150 $\mu \mathrm{m}$ ) may contain a large number of individuals and species of foraminifera that are rarely seen in large fractions, especially in environments rich in OM, where the dominant species are more abundant in small fractions (Shepherd et al. 2007). Our results confirm the importance of analyzing small fractions in mangrove environments.
Debenay y Thi-Luan 2006, Bernal et al. 2008, Mojtahid et al. 2009, Semensatto et al. 2009), pero inferior a los registrados para el cuerpo de agua principal del golfo (60 especies, Vargas 2011). Así mismo, la biodiversidad fue baja (índice de Shannon Weaver: 0-0.66). Las bajas abundancias y diversidad en los estuarios y manglares se deben a condiciones no óptimas de salinidad y pH para los FB (Mojtahid et al. 2009).

La composición de la fauna de FB estuvo dominada por una sola especie, $M$. fusca, con $61 \%$ del total. Esta especie también fue dominante, en el estuario de Tina Menor, Cantabria (Pascual et al. 2009). En el GU, M. fusca se encontró principalmente en los manglares del Atrato donde dominaron los sustratos limosos y \% L altos (hasta 90\%). Esta especie se ha presentado en ambientes con muy baja salinidad (Debenay et al. 2002, Murray 2006,), con \%L menores que 66\% (Murray 2006), en sedimentos con abundantes arcillas (Chatelet et al. 2009) y en ambientes estresados (Semensatto et al. 2009); no se favorece con depósitos de restos vegetales sobre los sedimentos (Chatelet et al. 2009).

La asociación de especies encontrada es característica de estos ambientes. Horton et al. (2003) observaron la dominancia de $M$. fusca, A. mexicana y $H$. canariensis en un ecosistema de manglar australiano. Ammobaculites exiguus se ha registrado en ambientes estuarinos someros donde la salinidad no excede 20 (Scott 2007), está asociada con sedimentos lodosos y puede ser tolerante a la exposición aérea (Semensatto et al. 2009). En los manglares del golfo, A. exiguus mostró preferencia por los sustratos areno lodosos de algunas localidades de bocas del Atrato. Por su parte, T. squamata, se ha caracterizado por encontrarse en sustratos finos (Murray 2006) y ricos en MO (Chatelet et al. 2009). En los manglares del GU estuvo relacionada con el \%L y, junto con $H$. canariensis, con la MO.

La especie calcárea más importante fue A. beccari. En una de las muestras de la ensenada de Rionegro representó el $100 \%$ relativo a otras especies. Es una especie común, pero tiene la capacidad de colonizar ambientes estuarinos y de manglar (Debenay et al. 2002, Diz y Francés 2008, Mojtahid et al. 2009). Se asocia con altos contenidos de MO y bajas concentraciones de oxígeno en los sedimentos (Scott 2007, Diz y Francés 2008). Su dominancia en la ensenada de Rionegro podría deberse a los niveles bajos de oxígeno registrados por la REDCAM.

Para el análisis de las relaciones entre los FB y los factores ambientales se tuvieron en cuenta las abundancias totales en las muestras y las condiciones ambientales en el momento de la recolección. Una debilidad del análisis reside en que las muestras fueron recolectadas en tres meses del año, en dos estaciones diferentes. No se realizó un análisis de variabilidad estacional, el cual sería sin duda valioso, pero requeriría un diseño de muestreo específico. El hecho de usar el total de FB (vivos + muertos) encontrados en el primer centímetro superficial implica que la relación con el medio ambiente sea de una asociación de más largo plazo que la estacional. 
Hydraulic energy is an abiotic factor influencing BF (Schonfeld 2002). This has a major effect on other variables such as grain size and OM. Grain size has a large influence on BF (Murray 2006), but in some cases it is difficult to discriminate the influence of other environmental variables (Debenay et al. 2002). Coarse sediments are typical of wave or current environments and fine sediments of quiet environments. The absence of foraminifera in the GU localities exposed to waves (headlands of the Atrato delta) can be attributed to their preference for low-energy areas that favor the deposition of OM (food); also, environments with heavy surf conditions vary so quickly that they do not allow the establishment of BF (Alve 1999). Moreover, current forces have negative impacts on richness and abundances (Schonfeld 2002). Overall, in the GU mangroves, the areas exposed to waves and currents had larger grain size and lower abundance of foraminifera, while sheltered and depositional environments had high \%M and higher abundance of foraminifera.

The effects of OM on BF are complex. Some studies show an increase or decrease in abundance of foraminifera with an increase or decrease of $\mathrm{OM}$ in sediments, while others show no influence (Chatelet et al. 2009). In this study, $\mathrm{BF}$ were absent in sediments with $\mathrm{OM}$ values $<5 \%$ and $>40 \%$, and more abundant in sediments with $15-30 \%$ OM. These results support the hypothesis proposed by Alve (1999), that OM favors the development of BF until it becomes toxic. Regarding richness, it decreases with increasing $\mathrm{OM}$ in the $\mathrm{GU}$ mangrove forests.

Low levels of dissolved oxygen have been reported in many of the GU locations where foraminifera were not found. Low levels of oxygen and carbonates may be due to high concentrations of OM (30\%-90\%) that produce anoxia and decrease $\mathrm{pH}$ due to oxygen consumption and $\mathrm{CO}_{2}$ production during its degradation.

The coastal waters of the eastern GU are influenced by pollution from hydrocarbons, fertilizers, and pesticides related to banana farming, the main economic activity of the region. In Turbo Bay there is high environmental degradation due to garbage, sewage, and maritime traffic, which coincided with low abundance and diversity of BF (only one of three samples contained foraminifera, with nine species). Hydrocarbons and pesticides have increased in León River, the main route of banana boats out to sea, and no foraminifera were found. The above results show that these locations are probably being affected by the increase in hydrocarbon values. Other studies have reported that aromatic hydrocarbons can be lethal to marine organisms. Low doses may inhibit physiological activities and cause pathological reactions (Sen Gupta 1999), and this may also be one of the causes of the low dissolved oxygen levels in the water.

The low occurrence of foraminifera in Rionegro Cove may be linked to human intervention and sediment type (high content of $\mathrm{OM}$ and plant debris). This forest suffered very strong degradation in 2004 and the REDCAM reports also
En investigaciones anteriores se ha observado que las fracciones pequeñas $(63-150 \mu \mathrm{m})$ pueden contener un gran número de individuos y especies de foraminíferos que raramente se observan en las fracciones grandes, especialmente en ambientes ricos en $\mathrm{MO}$, donde las especies dominantes pueden encontrarse mas abundantes en fracciones pequeñas (Shepherd et al. 2007). Los resultados del presente estudio confirman la importancia de analizar las fracciones pequeñas en ambientes de manglar.

La energía hidráulica es un factor abiótico influyente sobre los FB (Schonfeld 2002). Ésta ejerce un efecto importante sobre otras variables como el tamaño de grano y la MO. El tamaño de grano tiene gran influencia sobre los FB (Murray 2006), pero hay algunas ocasiones donde es difícil discriminar su influencia de la de otras variables ambientales (Debenay et al. 2002). Los sedimentos gruesos son típicos de ambientes con oleaje o corrientes y los finos de, ambientes tranquilos. La ausencia de foraminíferos en los lugares del GU expuestos al oleaje (salientes del delta del Atrato) se explica porque éstos prefieren zonas de baja energía donde se facilita el depósito de MO (alimento); además, en ambientes con fuerte oleaje las condiciones varían tan rápidamente que no permiten el establecimiento de los FB (Alve 1999). Asímismo, las fuerzas de las corrientes tienen impactos negativos en riqueza y abundancias (Schonfeld 2002). En general, en los manglares del GU se observó que los lugares expuestos al oleaje y corrientes presentaron mayor tamaño de grano y menores abundancias de foraminíferos, mientras que los ambientes resguardados y depositacionales presentaron altos \%L y mayores abundancias de foraminíferos.

Los efectos de la MO sobre los FB son complejos, ya que algunos estudios muestran aumento o decrecimiento en abundancias de foraminíferos con el aumento o disminución de la $\mathrm{MO}$ en los sedimentos, mientras que otros revelan no tener influencia (Chatelet et al. 2009). En este estudio, no se observaron foraminíferos en los sedimentos con valores de MO $<5 \%$ y $>40 \%$, y las abundancias fueron mayores en sedimentos con MO entre 15 y 30\%. Estos resultados apoyan la hipótesis de Alve (1999), de que la MO favorece el desarrollo de los FB hasta que llega a ser tóxica. En cuanto a la riqueza, en los manglares del GU disminuye cuando se incrementa la MO.

En muchas de las localidades del GU donde no se encontraron foraminíferos se han registrado valores bajos de oxígeno disuelto. Niveles bajos de oxígeno y de carbonatos podrían deberse a concentraciones de MO altas (30\%-90\%) que producirían anoxia y disminución del $\mathrm{pH}$ debido al consumo de oxígeno y producción de $\mathrm{CO}_{2}$ en su degradación.

Las aguas costeras del lado oriental del golfo se encuentran influenciadas por contaminación por fertilizantes, hidrocarburos y pesticidas relacionada con la agricultura del banano, principal actividad económica de la región. En bahía Turbo se presenta una alta degradación ambiental debida a basuras, aguas residuales y tráfico marítimo, que coincidió con baja abundancia y diversidad de FB (sólo en una de tres 
indicate low oxygen levels in the water. These sediments had the highest carbonate content of the studied mangroves (up to $57 \%$ compared to $6.5 \%$ for the other forests), with traces of clams or oysters. It is precisely here that the BF found were calcareous. This was expected because, since the waters have higher availability of calcium carbonate, individuals can build their calcareous shells more easily.

\section{CONCLUSIONS}

This study allowed identifying the main ecological factors acting on $\mathrm{BF}$ in the GU mangrove forests. Hydraulic energy is an important factor related to grain size and \%OM. The most abundant species was $M$. fusca and it was associated with \%M; T. squammata and $H$. canariensis showed a preference for localities with plenty of OM. In places with high human impact, there were low BF abundances, high nutrient concentrations, low oxygen levels, and hydrocarbons and pesticide pollution; A. beccarii, typical colonizer of contaminated environments, was found there. This species could be used as a bioindicator of environmental degradation.

The BF assemblages were similar to those of most estuarine environments around the world. There were two typical assemblages, one formed by A. salsum, A. mexicana, and $A$. beccari, and the other by $M$. fusca, $H$. canariensis, A. exiguus, T. squammata, A. exilis, A. americanus, T. inflata, and $H$. wilbertii.

Species such as $H$. canariensis and T. squammata were more abundant in the 63-150 $\mu \mathrm{m}$ size fraction, highlighting the importance of taking into account the small fractions in the analysis of BF in mangrove ecosystems.

\section{ACKNOWLEDGEMENTS}

This research was made possible due to funding from the Government of Antioquia (Colombia). Thanks to Mauricio Ruiz-Ochoa for his support and advice, and Ligia E Urrego for her valuable suggestions. Jose D Ramírez collaborated with the sedimentological analysis, and Mario A Jiménez and Jaime A Carmona helped in programming. Thanks also to the colleagues that participated in the Estuarine Expedition, Gulf of Urabá, Stage I, and field assistants for their collaboration, as well as the people of the region of Urabá for allowing sampling.

English translation by authors.

\section{REFERENCES}

Alongi DM, Robertson AI. 1992. Tropical Mangrove Ecosystems. American Geophysical Union, Washington, DC, 329 pp.

Alve E.1999. Colonization of new habitats by benthic foraminifera: A review. Earth-Sci. Rev. 46: 167-185.

Barker R. 1960. Taxonomic notes on the especies figured by H.B. Brady in his report on the foraminifera dredged by H.M.S muestras se hallaron foraminíferos, con nueve especies). En el río León, la principal ruta de salida de los barcos bananeros hacia el mar, se ha notado un incremento en los hidrocarburos y pesticidas, y allí no se encontraron foraminíferos. Los anteriores resultados muestran que estas localidades probablemente están siendo afectadas por el aumento en los valores de hidrocarburos. En otras investigaciones se ha registrado que los hidrocarburos aromáticos pueden ser letales para organismos marinos. Las dosis más bajas pueden inhibir actividades fisiológicas y causar reacciones patológicas (Sen Gupta 1999), además esto también puede ser uno de los causantes de los bajos valores de oxígeno disuelto en el agua.

La baja ocurrencia de foraminíferos en la ensenada de Rionegro podría tener que ver con la intervención antrópica y el tipo de sedimento (altos contenidos de MO y restos vegetales). Este bosque sufrió una degradación muy fuerte en 2004 y los reportes de REDCAM igualmente indican bajos contenidos de oxígeno en el agua. Estos sedimentos tuvieron los mayores porcentajes de carbonatos de los manglares estudiados (hasta $57 \%$ respecto a $6.5 \%$ en los otros bosques), con restos de conchas de almejas u ostras. Precisamente aquí, cuando se presentaron FB, éstos fueron calcáreos. Esto era de esperarse, pues al tener las aguas mayor disponibilidad de carbonato de calcio, los individuos pueden construir su concha calcárea más fácilmente.

\section{CONCLUSIONES}

Este estudio permitió determinar los principales factores ecológicos que actúan sobre los FB en los manglares del GU. La energía hidráulica es un factor importante, relacionada con el tamaño de grano y el \%MO. La especie más abundante, $M$. fusca, se encontró relacionada con el \%L; T. squammata y $H$. canariensis tuvieron preferencia por lugares con abundante MO. En los lugares con alta intervención antropogénica se dieron bajas abundancias de FB con altas concentraciones de nutrientes, bajos niveles de oxígeno y contaminación con hidrocarburos y pesticidas. Allí se presentó la especie $A$. beccarii, típica colonizadora de ambientes contaminados. Esta especie podría ser usada como bioindicadora de degradación ambiental.

Las asociaciones de FB encontradas son similares a las de la mayoría de ambientes estuarinos alrededor del mundo. Ocurrieron dos asociaciones, una conformada por A. salsum, A. mexicana y A. beccari, y otra por $M$. fusca, $H$. canariensis, A. exiguus, T. squammata, $A$. exilis, $A$. americanus, T. inflata y $H$. wilbertii.

Especies como $H$. canariensis y $T$. squammata fueron más abundantes en la fracción de 63-150 $\mu \mathrm{m}$, resaltando la importancia de tomar en cuenta las fracciones pequeñas en el análisis de FB en manglares.

\section{Agradecimientos}

Agradecemos a la Gobernación de Antioquia (Colombia) por el apoyo económico que hizo posible esta investigación. 
Challenger during the years 1873-1876. Vol. 9. Society of Economy Paleontology and Mineralogy.

Bernal G, Ruiz-Ochoa MA, Piedrahita MT, Restrepo E. 2008. Foraminíferos en los sedimentos superficiales del sistema lagunar de Cispatá y la interacción Río Sinú-Mar Caribe Colombiano. Bol. Ciencias de la Tierra 23: 5-20.

Boltovskoy E, Hincapié de Martínez S. 1983. Foraminíferos del manglar de Tesca, Cartagena, Colombia. Rev. Esp. Micropaleontol. 15: 205-220.

Buzas M, Severin K. 1982. Distribution and systematics of foraminifera in the Indian River, Florida. Smithson. Contrib. Paleobiol. 16: 1-73.

Buzas M, Smith R, Beem, K. 1977. Ecology and systematics of foraminifera in two thalassia habitats, Jamaica, West Indies. Smithson. Contrib. Paleobiol. 31: 139 pp.

Chatelet E, Debenay JP, Soulard R. 2004. Foraminiferal proxies for pollution monitoring in moderately polluted harbors. Environ. Pollut. 127: 27-40. http://dx.doi.org/10.1016/S0269-7491(03)00256-2.

Chatelet EA, Bout-Roumazeilles V, Riboulleau A, Trentesaux A. 2009. Sediment (grain size and clay mineralogy) and organic matter quality control on living benthic foraminifera. Rev. Micropaleontol. 52: 75-84. http://dx.doi.org/10.1016/j.revmic.2008.10.002

Corpourabá. 2011. En la Ensenada de Rionegro-Necoclí Avanza Recuperación de las Ostras del Manglar. Corporación para el Desarrollo Sostenible del Urabá. http://www.corpouraba.gov.co/ en-la-ensenada-de-rionegro-necocli-avanza-recuperacion-delas-ostras-del-manglar. Accessed on 26 February 2013.

Culver SJ. 1990. Benthic foraminifera of Puerto Rican mangrovelagoon systems: Potential for paleoenvironmental interpretations. Deep Sea Res. (B Oceanogr. Lit. Rev.) 37: 34-51. http://dx.doi.org/10.1016/S0198-0254(06)80381-X

Debenay JP, Thi-Luan B. 2006. Foraminiferal assemblages and the confinement index as tools for assessment of saline intrusion and human impact in the Mekong Delta and neighbouring areas (Vietnam). Rev. Micropaléontol. 49: 74-85. http://dx.doi.org/10.1016/j.revmic.2006.01.002

Debenay JP, Guiral M, Parra D. 2002. Ecological factors acting on the microfauna in mangrove swamps. The case of foraminiferal assemblages in French Guiana. Estuar. Coast. Shelf Sci. 55: 509-533. http://dx.doi.org/10.1006/ecss.2001.0906

Diz P, Francés G. 2008. Distribution of live benthic foraminifera in the Ría de Vigo (NW Spain). Mar. Micropaleontol. 66: 165-191. http://dx.doi.org/10.1016/j.marmicro.2007.09.001

Gooday AJ, Bernhard JM, Levin LA, Suhr SB. 2000. Foraminifera in the Arabian Sea oxygen minimum zone and other oxygendeficient settings: Taxonomic composition, diversity, and relation to metazoan faunas. Deep-Sea Res. II 47: 25-54. http://dx.doi.org/10.1016/S0967-0645(99)00099-5

Horton BP, Larcombe P, Woodroffe SA, Whittaker SA, Wright MR, Wynn C. 2003. Contemporary foraminiferal distributions of a mangrove environment, Great Barrier Reef coastline, Australia: Implications for sea-level reconstructions. Mar. Geol. 198: 225-243. http://dx.doi.org/10.1016/S0025-3227(03)00117-8

McCulloch I. 1977. Qualitative observations on recent foraminifera test with emphasis on the Eastern Pacific. University of Southern California, Los Angeles.

Mojtahid M, Jorissen F, Lansard B, Fontanier C, Bombled B, Rabouille C. 2009. Spatial distribution of live benthic foraminifera in the Rhone prodelta: Faunal response to a continental-marine organic matter gradient. Mar. Micropaleontol. 70: 177-200.

http://dx.doi.org/10.1016/S0025-3227(03)00117-8
Gracias a Mauricio Ruiz-Ochoa por su apoyo y asesoría, y a Ligia E Urrego por sus valiosos aportes. Jose D Ramírez colaboró con los análisis sedimentológicos de las muestras, y Mario A Jiménez y Jaime A Carmona ayudaron con la programación. Agradecemos también a los compañeros de Expedición Estuarina, golfo de Urabá, Fase I, por su acompañamiento, a los ayudantes de campo por su colaboración, así como a los habitantes de la región de Urabá por permitir los muestreos.

Montoya LJ. 2010. Dinámica oceanográfica del Golfo de Urabá y su relación con los patrones de dispersión de contaminantes y sedimentos. PhD thesis, Facultad de Minas, Universidad Nacional de Colombia.

Morrisey DJ, Skilleter GA, Ellis Burns JI, Kemp CE, Burt CE. 2003. Differences in benthic fauna and sediment among mangrove (Avicennia marina var. australasica) stands of diferent ages in New Zeland. Estuar. Coast. Shelf Sci. 56: 581-592. http://dx.doi.org/10.1016/S0272-7714(02)00208-1

Murray J. 2006. Ecology and applications of benthic foraminifera. Cambridge University Press, 426 pp.

Nooijer LJ, Duijnstee IAP, Bergman MJN, Van der Zwaan MJN. 2008. The ecology of benthic foraminifera across the Frisian Front, southern North Sea. Estuar. Coast. Shelf Sci. 78: 715-726. http://dx.doi.org/10.1016/j.ecss.2008.02.015

Parada C. 1991. Claves de identificación para géneros de foraminíferos. Curso Universidad Nacional de Colombia. Bogotá D.C.

Parada C, Pinto J. 1986. Foraminíferos bénticos recientes de isla Barú. Fondo FEN Colombia. Fondo FEN Colombia, Bogotá D.C., 212 pp.

Pascual A, Martínez García B, Rodríguez Lázaro J, Martín-Rubio M. 2009. Distribución de los foraminíferos bentónicos recientes en el estuario de Tina Menor (Cantabria). Geogaceta 47: 45-48.

Schonfeld J. 2002. A new benthic foraminiferal proxy for nearbottom current velocities in the Gulf of Cadiz, northeastern Atlantic Ocean. Deep-Sea Res. (I Oceanogr. Res. Pap.) 49: 1853-1875. http://dx.doi.org/10.1016/S0967-0637(02)00088-2

Schonfeld J, Alve E, Geslin E, Jorissen F, Korsun S, Spezzaferri S. 2012. The FOBIMO (FOraminiferal BIo-MOnitoring) initiative: Towards a standardised protocol for soft-bottom benthic foraminiferal monitoring studies. Mar. Micropaleontol. 94:1-13. http://dx.doi.org/10.1016/j.marmicro.2012.06.001

Scott DB. 2007. Monitoring in Coastal Environments using Foraminifera and Thecamoebian Indicators. Cambridge University Press.

Semensatto Jr. DL, Hideki Ferreira Funo R, Dias-Brito D, Coelho Jr. C. 2009. Foraminiferal ecological zonation along a Brazilian mangrove transect: Diversity, morphotypes and the influence of subaerial exposure time. Rev. Micropaleontol. 52: 67-74. http://dx.doi.org/10.1016/j.revmic.2008.06.004

Sen Gupta B. 1999. Modern Foraminifera. Kluwer Academic Publishers, $361 \mathrm{pp}$.

Shepherd AS, Rathburn AE, Pérez ME. 2007. Living foraminiferal assemblages from the Southern California margin: A comparison of the $>150$, 63-150, and $>63 \mu \mathrm{m}$ fractions. Mar. Micropaleontol. 65: 54-77.

http://dx.doi.org/10.1016/j.marmicro.2007.06.001 
Taborda-Marín A, Maldonado-Lizarazo C, Palacio-Baena JM, Vásquez-Arango JG. 2008. Participación comunitaria en el Golfo de Urabá: El caso del corregimiento Bocas del Atrato y la vereda El Roto, Municipio de Turbo, Antioquia. Rev. Gestión Ambiente 11: 97-108.

Tucker M. 1988. Techniques in Sedimentology. Blackwell Scientific Publications, Oxford.

Urrego LE, Molina EC, Suárez JA, Ruiz HY, Polanía J. 2010. Distribución, composición y estructura de los manglares del Golfo Urabá. En: Informe técnico del proyecto Expedición estuarina Golfo de Urabá, 2013. Gobernación de Antioquia, Medellín (Colombia).
Vanicek V, Juracic M, Bajraktarevic Z, Cosovic V. 2000. Benthic foraminiferal assemblages in a restricted environment. An example from Mjet lakes (Adriatic Sea, Croatia). Geol. Croatica 53: 269-279. http://dx.doi.org/10.1016/j.marmicro.2007.06.001

Vargas ME. 2011. Foraminíferos del Golfo de Urabá y su potencial como paleoindicadores y bioindicadores de cambios ecológicos. Msc Thesis, Facultad de Minas, Universidad Nacional de Colombia.

Wolfgang K. 1996. Ecological structuring and evolution of deep sea agglutinated foraminifera: A review. Rev. Micropaleontol. 39: 271-281.

http://dx.doi.org/10.1016/S0035-1598(96)90119-1

Received July 2012, received in revised form November 2012, accepted January 2013. 